\title{
Effect of salinity on sodium and chloride uptake, proline and soluble carbohydrate contents in three alfalfa varieties.
}

\author{
Mezni Majid ${ }^{1}$, Albouchi Ali ${ }^{2}$, Bizid Essia ${ }^{3}$ \\ ${ }^{1 .}$ Université de Carthage; Laboratoire des Productions Animales et Fourragères. INRAT, Rue Hédi Karray \\ 2049, Ariana, Tunisie. \\ ${ }^{2 .}$ Unité d'Agro-Sylvo-Pastoralisme. INRGREF, BP 10, 2080, Ariana, Tunisie. \\ ${ }^{3 .}$ Laboratoire de Physiologie Végétale, Faculté des Sciences de Tunis. Campus Universitaire, 1060, le \\ Belvédère, Tunisie.
}

\begin{abstract}
Salinity stress affected severely plant growth and production. Indeed, soil salinity represented one of the most important environmental stresses, which caused serious threats to agriculture and also results in the deterioration of environment. Accumulation of sodium, chloride, proline and soluble sugars was investigated in leaves, stems and roots of three alfalfa varieties (Hunterfield, Hyb.555 and Gabès) at the late bloom-early pod stage. The study was conducted in a greenhouse for 90 days of salt stress in whole-plants. Plants were irrigated with top water with four $\mathrm{NaCl}$ concentrations: $\left(0-2.5-5\right.$ and $\left.10 \mathrm{~g} . l^{-1}\right)$. Results showed that all varieties accumulated high $\mathrm{Na}^{+}$and $\mathrm{Cl}$ contents in leaves and stems. Gabès variety differed from Hunterfield and $\mathrm{Hyb} .555$ with $\mathrm{Na}^{+}$and $\mathrm{Cl}^{-}$contents significantly lower in leaves at the stressful treatments. Furthermore, Gabès proline content at 5 and $10 \mathrm{~g} . \mathrm{l}^{-1} \mathrm{NaCl}$ in three organs was significantly higher than in the introduced varieties. Proline content in leaves, stems and roots increased with the rise of salt in pots, reaching a significantly higher level for Gabès at the stressful treatment $\left(10 \mathrm{~g} . \mathrm{l}^{-1}\right)$. Soluble sugar content in leaf tissue was higher in Gabès than those in the introduced varieties at the stressful treatments $\left(5\right.$ and $\left.10 \mathrm{~g} . \mathrm{l}^{-1}\right)$. Contrary to the air parts (leaves and stems), soluble sugar contents in roots for Hunterfield and Hyb.555 are significantly higher, compared to Gabès variety, at the stressful treatment. This could be probably related to the difficulty in generating new leaves in Hunterfield and Hyb.555 varieties.
\end{abstract}

Keyword: Alfalfa; chloride; proline; Salinity; sodium; soluble carbohydrate.

\section{Introduction}

Salinity affects plant growth and development due to harmful ion effects and water stress caused by reduced osmotic potential in the soil solution (Da Silva et al., 2008). Indeed, osmotic constraint is the first difficulty plants are confronted under saline medium. Soluble salts in the soil reduce the osmotic potential which according to Strogonov (1964) becomes in a state of "physiological drought", particularly for plants that cannot adjust their osmotic potential. Salinity reduces the ability of plants to take up water (Munns, 2002 and 2005; ElSayed Saffan, 2008). However, the absorption of ions (sodium and chloride) and the synthesis of proline and glycine betaine (Meloni et al., 2004; Ouiza et al., 2010) and soluble sugars (Klages et al., 1999; Sakamoto and Murata, 2002; Gill et al., 2001; Abebe et al., 2003; Ashraf and Bashir 2003; Murakeözy et al., 2003; Ashraf and Harris, 2004; Ahmad et al., 2006), allow the plant to overcome such failure and to reestablish a water potential gradient which gives it the possibility to absorb water and restore plant turgor (Xiong and Zhu, 2002). Proline is an osmoprotectant found in many higher plants (Holmström et al., 2000). Proline has a higher solubility in water, and at higher concentrations it has little or no perturbing effect on macromolecule solvent interactions (Yancey et al., 1982; Timasheff, 1993). Proline accumulation is a common metabolic response of higher plants to salinity or water stress (Voetberg and Sharp, 1991; Ben Khaled et al., 2003; Khedr et al., 2003; Kavi Kishor et al., 2005; Mattana et al., 2005). Proline is accumulated by leaves of many higher plant species grown in saline environments (Ashraf and Bashir, 2003; Mishra and Gupta, 2005; Rabie and Almadini, 2005; Jiménez-Bremont et al., 2006; Ahmed et al., 2008; Cha-Um and Kirdmanee, 2009; Chutipaijit et al., 2009; Razavizadeh et al., 2009; Summart et al., 2010). In salinity or water stress, osmolyte accumulations in cells contribute substantially to cytoplasmic osmotic adjustment (Chinnusamy et al., 2005; Mishra and Gupta, 2005; El-Sayed Saffan, 2008; Turan et al., 2009). Selection for hydroxyproline-resistant mutants of barley and winter wheat (Dorffling et al., 1993) and Arabidopsis thaliana (Mattana et al., 2005) has succeeded in identifying lines that accumulate greater quantities of proline than wild type.

Parida and Das (2005) suggested that the ability of plants to tolerate salt is determined by multiple biochemical pathways that facilitate retention and/or acquisition of water, protect chloroplast functions, and maintain ion homeostasis. Indeed, proline and soluble sugar, while participating to the osmotic adjustment, they protect plant physiological reactions (Paleg et al., 1981; Abraham et al., 2003) and constitute a non toxic source of carbon, nitrogen and energy reserves (Joyce et al., 1992). Moreover, these organic osmotica reduce excessive 
accumulation of $\mathrm{Na}^{+}$and $\mathrm{Cl}^{-}$in aerial plant parts (Lone et al., 1987). Among "includer ", the most salt tolerant species are those that limit the $\mathrm{Na}^{+}$and $\mathrm{Cl}^{-}$transport to leaves, such as corn (Hajibagheri et al., 1987); sorghum (Pathamanabhan and Rao, 1976; Yang et al., 2003); soybean (Läuchli and Wieneke, 1976) and Arabidopsis thaliana (Shi et al., 2003). To compensate for this mineral deficiency, however, plants synthesize soluble organic substances of low molecular weight in order to re-establish osmotic balance. In saline condition, Kerepesi and Galiba, (2000) and Azevedo Neto et al., (2004) found that tolerant cultivars of wheat and different maize genotypes respectively accumulated more soluble carbohydrate than did sensitive ones. The aim of the present study is to compare soluble sugars, proline, sodium and chloride contents in alfalfa varieties grown under salt stress, with the objective to screen several lines tolerant for salt stress.

\section{Plant material and experimental conditions}

\section{Materials And Methods}

Three alfalfa varieties (Medicago sativa $\mathbf{L}$.) were used in this study. The work contained the native Gabès variety, compared to two introduced alfalfa varieties Hunterfield and Hyb.555. Plants were cultivated in greenhouse at natural conditions. The seedling was carried out in plastic pots containing a basic soil $\mathrm{pH}(8.2)$, rich in active chalk (13\%). It has a humidity varying between: $12.1 \%$ at wilting point, and $22.6 \%$ at field capacity. Pots were daily irrigated at the field capacity and continuously drained and drainage water was collected in small bottles. The quantities of water necessary for each irrigation treatment were determined using mini-lysimeters.

Each pot contained ten plants of the same variety. Young seedlings were first irrigated with tap water during establishment (20 days). At the four leaves trifoliate stage, young seedlings were irrigated with $\mathrm{NaCl}$ added water at 4 concentrations $\left(0-2.5-5\right.$ and $\left.10 \mathrm{~g} .1^{-1}\right)$. The experimental design included 12 treatments $(3$ varieties x 4 levels of salinity), with randomized 4 replications, resulting in a total of 48 pots and 480 plants.

Chemical analysis was carried on plant samples harvested at the late bloom-early pod stage that is a salt stress period of three months. The measurement of the soluble sugars and the proline was done on lyophilized samples of leaves, stems and roots from the three alfalfa varieties. Sugars were extracted with boiling alcohol at $70^{\circ}$ using a spectrophotometer set at $520 \mathrm{~nm}$ wavelength. The extraction and the dosage of the proline were based on the technical of Dreier and Goring, (1974). Readings were determined by spectrophotometer at a wavelength of $528 \mathrm{~nm}$. Extraction of ions was achieved using the nitric extraction technique (nitric acid to $0.5 \%$ ) on dry matter samples. The sodium was measured by a flame photometer (Eppendorf photometer). To avoid interference, dilutions were made so that $\mathrm{Na}^{+}$concentrations were lower then $30 \mathrm{mg} .1^{-1}$. Chlorides were determined by coulometry (Chloridometer Buchler-Cotlove). The machine was calibrated with $0.5 \mathrm{M} \mathrm{NaCl}$ solution.

\section{Statistical analysis}

Confidence intervals were calculated to the threshold of $95 \%$ probability. General Linear Models of SAS was used to explain the degree of significance of each factor and of the interactions between different factors. The Duncan test was used to compare treatment means for all studied parameters.

\subsection{Amino-acid contents}

\section{Results}

Proline was more abundant in leaves and roots and poor in stems. The proline content increased in the different organs with the rise of salt concentrations. Gabès variety distinguished from the others varieties by a significant proline level in leaves, stems and roots under the stressful treatment. The introduced varieties had similar proline contents, particularly in stems (figure1). This was confirmed by the analysis of variance what is showed a highly significant effect for variety, salinity and their interaction on proline contents in the different organs of the three tested varieties. The Duncan test ranked the varieties in the following order: Gabès $\geq$ Hyb.555 > Hunterfield. 


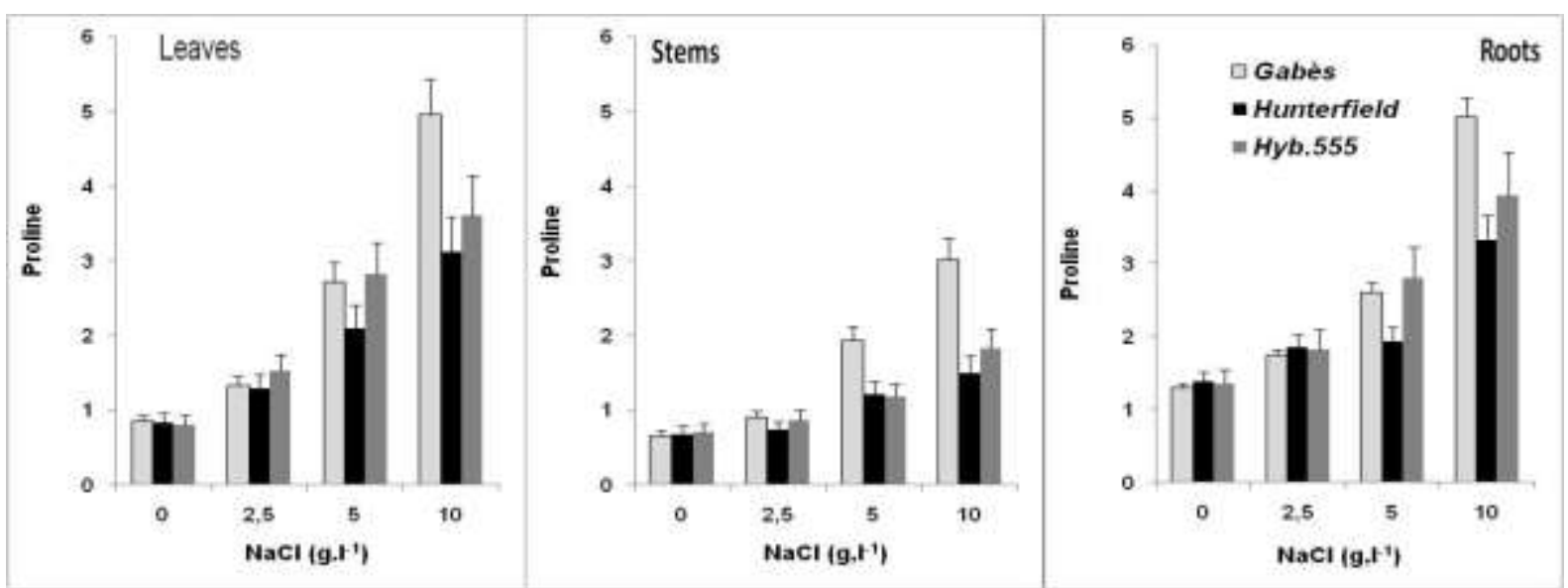

Figure 1. Proline contents (mg. $\left.\mathrm{g}^{-1} \mathrm{DM}\right)$ in leaves, stems and roots, after three months of salt stress. Intervals of confidence were calculated at $\alpha=95 \%$ probability level.

\subsection{Soluble carbohydrates}

The soluble sugars varied with the intensity of salt and depended on the plant organs. Indeed, the leaves soluble sugars of Gabès increased in concomitance with the rise of the intensity of the salt in pots and reached a significantly higher compared to Hunterfield and Hyb.555 varieties, at the stressful treatment $\left(10 \mathrm{~g} .1^{-1} \mathrm{of} \mathrm{NaCl}\right)$. Besides, the evolution of this carbohydrate in stem tissues of Gabès variety was not affected by the rise of $\mathrm{NaCl}$ in the medium. In contrast, the increasing of salt resulted in a decrease in leaves soluble sugar contents of Hyb.555 and especially Hunterfield. In root tissues, the soluble sugars increased strongly especially in the introduced varieties. However, the Gabès sugar contents stayed significantly lower compared to Hunterfield and $H y b .555$ varieties at the most stressful treatment (figure 2).

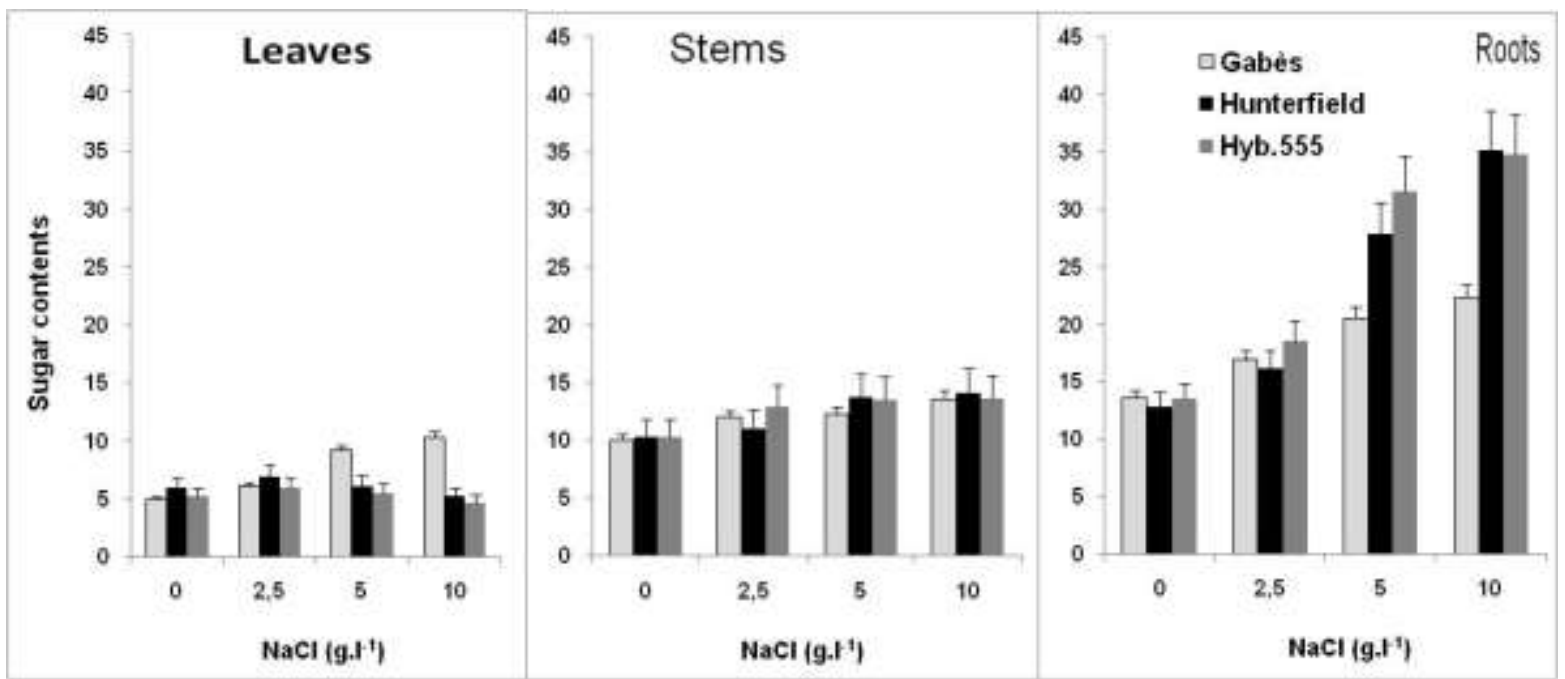

Figure 2. Sugar contents (mg. $\left.\mathrm{g}^{-1} \mathrm{DM}\right)$ in leaves, stems and roots, after three months of salt stress. Intervals of confidence were calculated at $\alpha=95 \%$ probability level.

\subsection{Chloride and Sodium contents}

Alfalfa exposure to salt stress for long time (three months) resulted in a very important chloride load in the aerial parts, particularly in leaves for all three varieties. However, an important difference for $\mathrm{Cl}^{-}$ concentration was observed between varieties. Indeed, Gabès variety accumulated less $\mathrm{Cl}^{-}$content in leaves than Hyb.555 and Hunterfield. Compared to the other varieties, Hunterfield had a systematically higher $\mathrm{Cl}^{-}$content in leaves.

Concerning $\mathrm{Na}^{+}$, results showed a significant difference in the sodium accumulation between the three alfalfa varieties. The $\mathrm{Na}^{+}$content in leaves, stems and roots of the three varieties rose with the rise of salt in the medium. Indeed, Gabès variety accumulated less $\mathrm{Na}^{+}$in all parts, compared to Hyb.555 and Hunterfield varieties, especially in leaves. Hyb.555 and particularly Hunterfield accumulated more $\mathrm{Na}^{+}$in leaves. Compared to leaves and stems, roots had the lowest $\mathrm{Na}^{+}$content in the three varieties. For Hunterfield, the invasion of the leaf tissue by $\mathrm{Na}^{+}$was proportional to $\mathrm{NaCl}$ concentration in the medium (figure 3). 


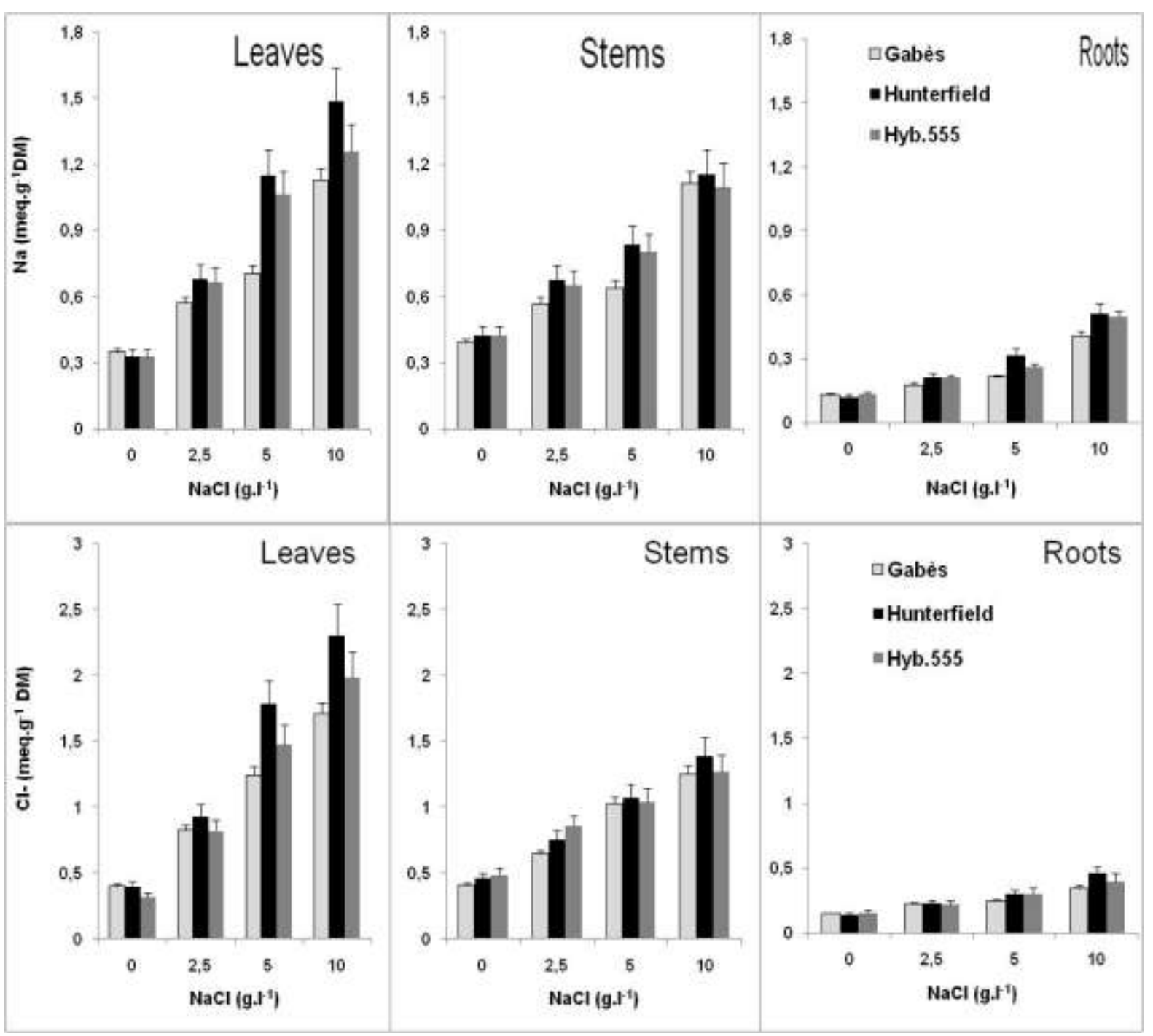

Figure 3. Sodium and chloride contents in leaves, stems and roots, after three months of salt stress. Intervals of confidence were calculated at $\alpha=95 \%$ probability level.

\section{Discussion}

The salt stress disrupted the growth and the mineral nutrition in cultivated plants by an osmotic effect (difficulty to uptake water) or by a toxic effect (excessive accumulation of $\mathrm{Na}^{+}$and $\mathrm{Cl}^{-}$) especially in leaves (Munns and Tester, 2008). Proline content increased in all organs of the three alfalfa varieties with increasing $\mathrm{NaCl}$ in the medium, but with a higher intensity for Gabès. The rise of the proline (compatible solutes Chen and Murata, 2002) in Gabès tissue, in response to the medium enrichment with sodium chloride allows it to attenuate the invasion of its organs by the sodium and chlorine (López et al., 2008), and to adjust its osmotic potential (Mezni, 1999; Mishra and Gupta, 2005; Turan et al., 2009). Soluble sugars also participated to the osmotic adjustment in plants exposed to the salt stress. For the Gabès variety and at the most stressful treatments, the soluble sugar contents in leaves were higher than those of Hunterfield. In the roots, the situation is different than what has been observed. Root tissues of the two introduced varieties had higher soluble sugar contents. For Hunterfield and Hyb.555, the richness in soluble sugars in roots resulted from the acceleration of leaf senescence and the difficulty to generate new leaves. According to Skinner et al., (1999); Ta et al.,(1990) and Erice et al., (2007), the soluble sugars and vegetative storage proteins of the collar and taproots were be mobilized to support the growth and the establishment of new photosynthetic active leaves, after defoliation.

Results showed that the three alfalfa varieties exported high quantities of $\mathrm{Na}^{+}$and $\mathrm{Cl}^{-}$into leaves and stems, which confirms the "inclusive" character of these varieties. This character was proven by similar $\mathrm{Na}^{+}$and $\mathrm{Cl}^{-}$accumulation in leaves. These quantities were, however, more important then those accumulated in roots. In Hunterfield, the excessive accumulation of $\mathrm{Na}^{+}$and $\mathrm{Cl}^{-}$reached toxic levels in leaf tissue, thus causing an important reduction in growth followed by a drying of aerial plant parts and the subsequent death of plants (Mezni et al., 1999). In contrast, the $\mathrm{Na}^{+}$accumulation in Gabès leaf tissue was lower, compared to the 
introduced varieties (Mezni et al., 2002; Munns, 2002; Munns and Tester, 2008). In addition, the $\mathrm{Na}^{+}$content in Gabès stems exceeded that in leaves. This suggested that part of the sodium in the leaves of this variety is reexported towards stem through the phloem sap. This type of $\mathrm{Na}^{+}$"trapping" in Gabès stems constitutes an efficient way to preserve physiological activities such as photosynthesis in leaves. Such behavior has been reported as a character of salt tolerance, in alfalfa and barley (Noble et al., 1984; Cramer et al., 1994).

Based on the $\mathrm{Na}^{+}$and $\mathrm{Cl}^{-}$uptake data, proline and soluble carbohydrate contents, it appears that salt stress increased the accumulation of $\mathrm{Na}^{+}$and $\mathrm{Cl}^{-}$particularly in the introduced varieties where they reached a toxic level in leaves. Results also suggest that the relative tolerance of Gabès variety to salt stress is related to its ability to conserve photosynthetic activity and to maintain higher proline and carbohydrates in leaves. Such osmolytes participate to osmotic adjustment. Moreover, the study pointed out the prominence of Gabès as a salt tolerant variety in the alfalfa selection program.

\section{Acknowledgements}

This study was performed within the support of Ministry of Higher Education and Scientific Research through the financing of research work.

\section{Referencesbibliographiques}

[1] Abebe T., Guenzi A.C., Martin B., Cushman J.C., 2003. Tolerance of mannitol-accumulating transgenic wheat to water stress and salinity. Plant Physiol., 131: 1748-1755.

[2] Abraham E., Rigo G., Székely G., Nagy R., Koncz C., Szabados L., 2003. Light-dependent induction of proline biosynthesis by abscisic acid and salt stress is inhibited by brassinosteroid in Arabidopsis. Plant Mol. Biol., 51: 363-372.

[3] Ahmad M.S.A., Ali Q., Bashir R., Javed F., Khadija Alvi A., 2006. Time course changes in ionic composition and total soluble carbohydrates in two barley cultivars at seedling stage under salt stress. Pak. J. Bot., 38(5): 1457-1466.

[4] Ahmed A., Khalafallah T., Zinab K.M., Abd El-Gawad A., 2008. Tolerance of seven faba bean varieties to drought and salt stresses. Res. J. of Agri. and Biol. Sci., 4(2): 175-186.

[5] Ashraf M., Bashir A., 2003. Salt stress induced changes in some organic metabolites and ionic relations in nodules and other plant parts of two crop legumes differing in salt tolerance. Flora, 198(6): 486-498.

[6] Ashraf M., Harris P.J.C., 2004. Potential biochemical indicators of salinity tolerance in plants. Plant Sci., 166: 3-16.

[7] Azevedo Neto A.D., Prisco J.T., Enéas-Filho J., Lacerda C.F., Vieira Silva J., Alves da Costa P.H., Gomes-Filho E., 2004. Effects of salt stress on plant growth, stomatal response and solute accumulation of different maize genotypes. Braz. J. Plant Physiol., 16(1): 31-38.

[8] Ben Khaled L., Gõmez A.M., Honrubia M., Oihabi A., 2003. Effet du stress salin en milieu hydroponique sur le trèfle inoculé par le Rhizobium. Agronomie, 23: 553-560.

[9] Cha-Um S., Kirdmanee C., 2009. Effect of salt stress on proline accumulation, photosynthetic ability and growth characters in two maize cultivars. Pak. J. Bot., 41(1): 87-98.

[10] Chen T.HH., Murata N., 2002. Enhancement of tolerance of abiotic stress by metabolic engineering of betaines and other compatible solutes. Plant Biol., 5: 250-257.

[11] Chinnusamy V., Jagendorf A., Zhu J.-K., 2005. Understanding and improving salt tolerance in plants. Crop Sci., 45: 437-448.

[12] Chutipaijit S., Cha-Um S., Sompornpailin K., 2009. Differential accumulations of proline and flavonoids in indica rice varieties against salinity. Pak. J. Bot., 41(5): 2497-2506.

[13] Cramer G. R., Alberico G. J., Schmidt C., 1994. Salt tolerance is not associated with the sodium accumulation of two Maize hybrids. Aust. J. Plant Physiol., 21: 675-692.

[14] Da Silva E.C., Mansur R.J., Nogueira C., De Araujo F.P., De Melo N.F., De Azevedo Neto A.D., 2008. Physiological responses to salt stress in young umbu plants. Environ. and Exper. Botany, 63: 147-157.

[15] Dorffling K., Dorffling H., Lesselich G., 1993. In vitro selection and regeneration of hydroxyprolin-resistant lines of winter wheat with increased proline content and increased frost tolerance. J. of Plant Physiol., 142: 222-225.

[16] Dreier W., Goring M., 1974. Der einfluss hoher salzkon zentratimen auf verschieden physiologische parameter von maïswuzeen. Win Z. der HU Berlin. Nath.Naurrwiss R., 23: 641-644.

[17] El-Sayed Saffan S., 2008. Effect of salinity and osmotic stresses on some economic plants. Res. J. Agric. \& Biol. Sci., 4(2): 159166.

[18] Erice G., Irigoyen J.J., Sanchez-Diaz M., Avice J.C., Ourry A., 2007. Effect of drought, elevated $\mathrm{CO}_{2}$ and temperature on accumulation of $\mathrm{N}$ and vegetative storage proteins (VSP) in taproot of nodulated alfalfa before and after cutting. Plant Sci., 172: 903-912.

[19] Gill P.K., Sharma A.D., Singh P., Bhullar S.S., 2001. Effect of various abiotic stresses on the growth, soluble sugars and water relations of Sorghum seedlings grown in light and darkness. Bulg. J. Plant Physiol., 27(12): 72-84.

[20] Hajibagheri M. A., Harvey D. M. R., Flowers T. J., 1987. Quantitative ion distribution within root cells of salt-sensitive and salttolerant maize varieties. New Phytol., 105: 367-379.

[21] Holmström K.O., Somersalo S.I., Mandal A., Palva T.E., Welin B., 2000. Improved tolerance to salinity and low temperature in transgenic tobacco producing glycine betaine. J. of Experimental Botany, 51(343): 177-185.

[22] Jiménez-Bremont J.F., Becerra-Flora A., Hernández-Lucero E., Rodríguez-Kessler M., Acosta-Gallegos J.A., Ramírez-Pimentel J.G., 2006. Proline accumulation in two bean cultivars under salt stress and the effect of polyamines and ornithine. Biologia Plantarum, 50(4): 763-766.

[23] Joyce P. A.,Aspinall D., Paleg L. G., 1992. Photosynthesis and the accumulation of proline in response to water deficit. Aust. J. Plant Physiol., 19: 249-261.

[24] Kavi Kishor P.B., Sangam S., Amrutha R.N., Sri Laxmi P., Naidu K.R., Rao K.R.S.S., Sreenath Rao, Reddy K.J., Theriappan P., Sreenivasulu N., 2005. Regulation of proline biosynthesis, degradation, uptake and transport in higher plants: Its implications in plant growth and abiotic stress tolerance. Current Sci., 88(3): 424-438.

[25] Kerepesi I., Galiba G., 2000. Osmotic and salt stress-induced alteration in soluble carbohydrate content in wheat seedlings. Crop Sci., 40: 482-487. 
[26] Khedr A.H., Abbas M.A., Abdel Wahid A.A., Quick P. W., Abogadallah G.M., 2003. Proline induces the expression of salt-stressresponsive proteins and may improve the adaptation of Pancratium maritimum to salt-stress. J. of Exp. Botany, 54(392): 2553-2562.

[27] Klages K., Boldingh H., Smith G.S., 1999. Accumulation of myo-inositol in Actinidia seedlings subjected to salt stress. Annals of Botany, 84: 521-527.

[28] Läuchli A., Wieneke J., 1979. Studies on growth and distribution of $\mathrm{Na}^{+}$and $\mathrm{Cl}^{-}, \mathrm{K}^{+}$in Soybean varieties differing in salt tolerance. Z. Pflanzenernaehr Bodenkd, 142: 3-13.

[29] Lone M.I., Kueh J.S.H., Wyn Jones R.G., Bright S.W.J., 1987. Influence of proline and glycinebetaine on salt tolerance of cultured barley embryos. J. of Exp.Botany, 38(188): 479-490.

[30] López M., Tejera N.A., Lluch C., 2008. Differential strategies of the model legumes Lotus japonica and Medicago truncatula in the adaptation to salt stress: Photosynthetic and nutritional responses. American J. of Plant Physiol., 3(3): 121-130.

[31] Mattana M., Biazzi E., Consonni R., Locatelli F., Vannini C., Provera S., Coraggio I., 2005. Overexpression of Osmyb4 enhances compatible solute accumulation and increases stress tolerance of Arabidopsis thaliana. Physiol. Plantarum, 125(2): $212-223$.

[32] Meloni D.A., Gulotta M.R., Martinez C.A., Oliva M.A., 2004. The effects of salt stress on growth, nitrate reduction and proline and glycinebetaine accumulation in Prosopis alba. Braz. J. Plant Physiol., 16(1): 39-46.

[33] Mezni M., 1999. Capacité de régénération de la luzerne pérenne (Medicago sativa L.), en conditions de stress salin. Comparaison entre la variété locale Gabès et deux cultivars introduits Hyb.555 et Hunterfield. Thèse Doctorat Biologie, Université Tunis II, Fac. Sci. Tunis, 193p.

[34] Mezni M., Albouchi A., Bizid E., Hamza M., 2002. Effet de la salinité des eaux d'irrigation sur la nutrition minérale chez trois variétés de luzerne pérenne (Medicago sativa L.). Agronomie, 22: 283-291.

[35] Mezni M., Bizid E., Hamza M., 1999. Effets de la salinité des eaux d'irrigation sur la survie et la croissance de trois cultivars de luzerne pérenne (Medicago sativa L.). Fourrages, 158: 169-178.

[36] Mishra, N. and Gupta A.K., 2005. Effect of salt stress on proline metabolism in two high yielding genotypes of green grain. Plant Sci., 169: 331-339.

[37] Munns R., 2002. Comparative physiology of salt and water stress. Plant, Cell \& Environ., 25: 239-250.

[38] Munns R., 2005. Genes and salt tolerance: bringing them together. New Phytologist, 167(3): 645-663.

[39] Munns R. and Tester M., 2008. Mechanisms of Salinity Tolerance. Annu. Rev. Plant Biol., 59: 651-681.

[40] Murakeözy É.P., Nagy Z., Duhazé C., Bouchereau A., Tuba Z., 2003. Seasonal changes in the levels of compatible osmolytes in three halophytic species of inland saline vegetation in Hungary. J. of Plant Physiol., 160(4): 395-401.

[41] Noble C.L., Halloran G.M., West D.W., 1984. Identification and selection for salt tolerance in Lucerne (Medicago sativa L.), .Aust. J. Agric. Res., 35: 239-252.

[42] Ouiza D.Z., Belkhodja M., Bissati S., Hadjadj S., 2010. Effet du stress salin sur l'accumulation de proline chez deux espèces d'Atriplex Halimus (L.) et Atriplex Canescens (Pursh) Nutt., European J. of Sci. Res., 41(2): 249-260.

[43] Paleg L. G., Douglas T. J., Van Daal A., Keech D. B., 1981. Proline, betaine and other organic solutes protect enzymes against heat inactivation. Aust. J. Plant Physiol., 8: 107-114.

[44] Parida A.K. and Das A.B., 2005. Salt tolerance and salinity effects on plants: a review. Ecotoxicology and Environ. Safety, 60: 324349.

[45] Pathamanabhan G., Rao J.S., 1976. Note on potassium as a possible index for screening Sorghum varieties for salt tolerance. Indian J. Agric. Sci., 46: 392-394.

[46] Rabie G.H., Almadani A.M., 2005. Role of bioinoculants in development of salt tolerance of Vicia faba plants under salinity stress. Afric. J. biotechn., 4(3): 210-222.

[47] Razavizadeh R., Ehsanpour A.A., Ahsan N., Komatsu S., 2009. Proteome analysis of tobacco leaves under salt stress. Peptides 30 : $1651-1659$

[48] Sakamoto A., Murata N., 2002. The role of glycine betaine in the protection of plants from stress: clues from transgenic plants. Plant, Cell, Environ. 25: 163-171.

[49] Shi H., Lee B., Wu S.L., Zhu J.K., 2003. Overexpression of a plasma membrane $\mathrm{Na}^{+} / \mathrm{H}^{+}$antiporter gene improves salt tolerance in Arabidopsis thaliana. Nature Biotechn., 21(1): 81-85.

[50] Skinner R.H., Morgan J.A., Hanson J.D., 1999. Carbon and nitrogen reserve remobilization following defoliation: Nitrogen and elevated $\mathrm{CO}_{2}$ effects. Crop Sci., 39:1749-1756.

[51] Strogonov B. P., 1964. Physiological basis of salt tolerance. Trad.par Isr. Progr. for Scientific Translations, 279p.

[52] Summart J., Thanonkeo P., Panichajakul S., Prathepha P., McManus M.T., 2010. Effect of salt stress on growth, inorganic ion and proline accumulation in Thai aromatic rice, Khao Dawk Mali 105, callus culture. Afr. J. Biotechnol., 9: 145-152.

[53] Ta T.C., MacDowall F.D.H., Faris M.A., 1990. Utilization of carbon and nitrogen reserves of alfalfa roots in supporting $\mathrm{N}_{2}$-fixation and shoot regrowth. Plant Soil, 127: 231-236.

[54] Timasheff S.N., 1993. The control of protein stability and association by weak interactions with water: how do solvents affect these processes? Annu. Rev. Biophys. Biomol. Struct., 22: 67-97.

[55] Turan M.A., Awad Elkarim A.H., Taban N., Taban S., 2009. Effect of salt stress on growth, stomatal resistance, proline and chlorophyll concentrations on maize plant. Afr. J. Agric. Res., 4(9): 893-897.

[56] Voetberg G.S., Sharp R.E., 1991. Growth of the maize primary root in low water potentials. III. Roles of increased proline depositions in osmotic adjustment. Plant Physiol., 96(4): 1125-1130.

[57] Xiong L., Zhu J.-K., 2002. Molecular and genetic aspects of plant responses to osmotic stress. Plant, Cell, Environ., 25: $131-139$.

[58] Yancey P. H., Clark M. E., Hand S. C., Bowlis R. D., Somero G. N., 1982. Living with water stress: evolution of osmolyte system. Science, 217: 1214-1222.

[59] Yang W.J., Richa P.J., Axtell J.D., Wood K.V., Bonham C.C., Ejeta G., Mickelbart M.V., Rhodes D., 2003. Genotypic Variation for Glycinebetaine in Sorghum. Crop Sci., 43(5): 162-169. 